\title{
PERHITUNGAN STRUKTUR BETON DAN PERBANDINGAN PERHITUNGAN BIAYA MENURUT SNI DT 91-00008-2007 DAN SK SNI T-15-1991-03 (STUDI KASUS GEDUNG BINA MARGA DAN CIPTA KARYA KABUPATEN ACEH BESAR)
}

\author{
SRI INDAH SETIYANINGSIH
}

Dosen Kopertis Wilayah I DPK Universitas Muhammadiyah Aceh

\begin{abstract}
ABSTRAK
Material dan biaya sangat berpengaruh dalam pembangunan suatu proyek konstruksi, maka perhitungan kebutuhan material dan biaya struktur beton ini adalah untuk mengetahui besarnya kebutuhan material dan biaya dalam pembangunan suatu gedung. Artikel ini merupakan studi kasus terhadap pembangunan gedung Bina Marga dan Cipta Karya Kabupaten Aceh Besar, Propinsi Aceh. Bagian struktur yang ditinjau dalam penulisan ini adalah sloof, kolom, balok lantai dan ring balok. Dalam artikel ini juga dihadirkan analisis terhadap perbandingan metode dalam menghitung biaya yaitu menurut SNI DT 91-00008-2007 yang didapat dari pengelola proyek dan menurut SK SNI T-15-1991-03 yang dilakukan oleh penulis. Hasil yang diperoleh adalah bahwa terdapat perbedaan perhitungan yaitu kelebihan biaya sebesar Rp 141.315.100,00 atau 24,81\% dari SNI 2007 terhadap SK SNI T-15-1991-03.
\end{abstract}

Kata kunci : material, biaya, struktur beton, SNI 2007, SK SNI T-15-1991-03.

\begin{abstract}
PENDAHULUAN
Pemerintah Provinsi Aceh dalam mewujudkan keberlangsungan sistem pemerintahan terus berupaya meningkatkan sarana dan prasarana yang dibutuhkan oleh Instansi Pemerintahan dalam melaksanakan tugasnya melayani masyarakat..
\end{abstract}

Dalam upaya mendukung program kesejahteraan masyarakat tersebut, Pemerintah Aceh melakukan Pembangunan Gedung Dinas Bina Marga Dan Cipta Karya Kabupaten Aceh Besar. Sumber dana untuk proyek pembangunan ini berasal dari Otonomi Khusus Kabupaten Aceh Besar untuk anggaran tahun 2010.

Pelaksana proyek diharuskan menyediakan material yang cukup dan tidak terhambat pada saat melakukan pekerjaan di lapangan, oleh karena itu penulis tertarik untuk mencoba menguraikan keperluan secara keseluruhan untuk kebutuhan pengadaan material selama pekerjaan proyek itu berlangsung.

Tujuan dari penelitian ini adalah untuk mengetahui dan memperoleh nilai kebutuhan material dan biaya yang dibutuhkan pada bagian pekerjaan struktural gedung serta membandingkan metode perhitungannya menurut SK SNI T-15-1991-03 dengan perhitungan yang telah dilakukan oleh pegelola proyek yang berdasarkan SNI 2007. . Adapun bagian struktur yang ditinjau adalah: sloof, kolom, balok lantai, dan ring balok. Batasan perhitungan yang dilakukan adalah untuk tinjauan keperluan material beton (semen, pasir, kerikil dan air) dan pembesian (tulangan dan kawat ikat) untuk bagian struktural gedung. 


\section{TINJAUAN KEPUSTAKAAN}

\section{Beton Struktural}

\section{a. Sloof}

Sloof adalah balok beton yang berfungsi sebagai pendukung beban di atas pondasi (Sutaryo dan Kusdjono, 1984).

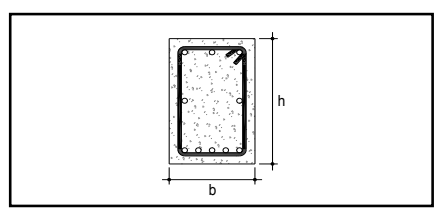

Gambar 2.1 Sloof

Volume $=b \times h \times L \times n \ldots \ldots .$.

\section{b. Kolom}

Dipohusodo (1996 : 287), menyebutkan kolom adalah komponen struktur bangunan yang tugas utamanya menyangga beban aksial tekan vertikal.

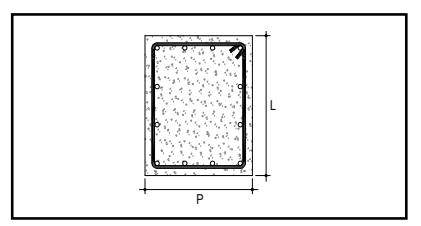

Gambar 2.2 Kolom

Volume $=\mathrm{P} \times \mathrm{L} \times \mathrm{h} \times \mathrm{n}$.

c. Balok lantai

Sutaryo dan Kusdjono (1984), mengatakan bahwa balok adalah kayu/beton maupun baja yang dipasang dalam didalam ruangan untuk menahan rangka langit-langit plafon. Untuk mengetahui volume pekerjaan balok dapat diperoleh dengan menggunakan rumus :

Volume $=b \times h \times L \times n$.........(2.3)

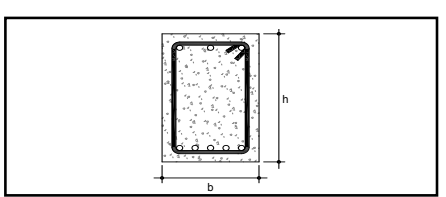

Gambar 2.3 Balok lantai

\section{d. Ring balok}

Ring balok adalah suatu struktur bangunan berbentuk balok yang berfungsi untuk menahan dan menopang beban atap (langit-langit dan kuda-kuda) dan memindahkan ke struktur dibawahnya.

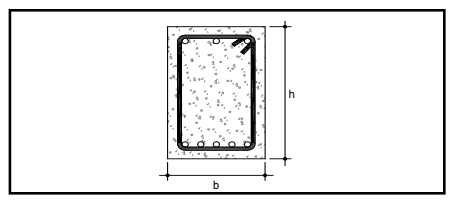

Gambar 2.4 Ring balok

Volume $=b \times h \times L \times n$......(2.4)

\section{Pekerjaan Pembesian}

Untuk menghitung volume tulangan yang memakai kait $1 / 4$ lingkaran $\left(90^{\circ}\right)$ :

$K=\pi \cdot\left(D+1 / 2 d_{b}\right)$

- $a=12 d_{b}+1 / 4 K$

- $b=L-2$ (Selimut beton) $+\left(n 40 d_{b}\right)$

- Panjang seluruhnya (Ps) $=2 a+b$

- Panjang keseluruhan $(P k)=P s \times$ Jumlah tulangan

- Total panjang keseluruhan (Total $P k)=P k x$ Jumlah tipe balok yang sama (2.10)

- Berat total $=$ Total Pk $x$ Berat $(\mathrm{Kg} / \mathrm{m})$

1. Untuk menghitung volume tulangan yang memakai kait $1 / 2$ lingkaran $\left(180^{\circ}\right)$ :

- $a=4 d_{b}+1 / 2 K$

- $\mathrm{b}=\mathrm{L}-2$ (Selimut beton) + (n 40 $\left.d_{b}\right)$.

- Panjang seluruhnya (Ps) $=2 a+b \ldots \ldots$. (2.14)

- Panjang keseluruhan $(P k)=P s \times$ Jumlah tulangan 
- Total panjang keseluruhan (Total Pk) = Pk x Jumlah tipe balok yang sama ...... (2.16)

- $\quad$ Berat total $=$ Total $\mathrm{Pk} \times$ Berat $(\mathrm{Kg} / \mathrm{m})$ (2.17)

2. Untuk Menghitung volume tulangan sengkang :

- $\quad K=\pi \cdot\left(D+1 / 2 d_{b}\right)$

- $a=1 / 4 \mathrm{~K}$

- $\mathrm{b}=\mathrm{h}-2$ (Selimut beton)

- $\quad c=b-2$ (Selimut beton)

- $d=6 d_{b}+\frac{135}{360} \times K$

- Panjang seluruhnya (Ps) $=3 a+2 b+2 c$ $+2 d$

- Berat $=$ Ps $\times$ Berat $(\mathrm{Kg} / \mathrm{m})$

3. Untuk menghitung volume tulangan pokok:

- $\quad K=\pi \cdot\left(D+1 / 2 d_{b}\right)$

- $\quad a=4 d_{b}+1 / 2 K$

- $\mathrm{b}=\mathrm{h}-2$ (Selimut beton) $+\left(40 \mathrm{~d}_{\mathrm{b}}\right)$ (2.27)

- Panjang seluruhnya (Ps) $=a+b \ldots$ (2.28)

- Panjang keseluruhan $(P k)=P s \times$ Jumlah tulangan

- $\quad$ Total panjang keseluruhan $($ Total $P k)=P k x$ Jumlah tipe kolom yang sama (2.30)

- Berat total $=$ Total Pk $\times$ Berat $(\mathrm{Kg} / \mathrm{m})$ (2.31)

\section{Estimasi Biaya Pelaksanaan}

Niron (1980) menyatakan bahwa analisa BOW (Burgerlijke Openbare Werken) merupakan sumber suatu rumusan penentuan harga satuan tiap jenis pekerjaan. Untuk menghitung biaya bahan digunakan rumus sebagai berikut:

$\mathrm{C}=A i \times b \times h i$

\section{Faktor Nilai Kehilangan Penggunaan Material}

Menurut Soedradjat (1984), besarnya biaya tak terduga pada pelaksanaan beton bertulang adalah berkisar antara 5 sampai $15 \%$.

\section{METODE PENELITIAN}

\section{Material Yang Digunakan}

Beton

Menggunakan mutu beton K-225 dimana komposisi campurannya adalah 1 Pc (portland cement) : 2 Ps (pasir) : $3 \mathrm{Kr}$ (kerikil). 
Tabel 3.1 Perbandingan campuran beton berdasarkan berat (tiap $1 \mathrm{~m}^{3}$ beton) berdasarkan SK SNI T-151991-03

\begin{tabular}{|c|c|c|c|c|c|c|c|c|c|}
\hline $\begin{array}{l}\text { Mutu } \\
\text { Beton }\end{array}$ & $\begin{array}{c}\text { Rencana } \\
\text { Slumn }\end{array}$ & $\begin{array}{c}\text { Faktor Air } \\
\text { Semen }\end{array}$ & Air & $\begin{array}{c}\text { Semen } \\
(\mathrm{Pc})\end{array}$ & $\begin{array}{l}\text { Pasir } \\
\text { (Ps) }\end{array}$ & $\begin{array}{c}\text { Kerikil } \\
(\mathrm{Kr})\end{array}$ & \multicolumn{3}{|c|}{ Perbandingan } \\
\hline $\mathrm{Kg} / \mathrm{Cm}^{2}$ & $\mathrm{Cm}$ & (FAS) & Kg & $\mathrm{Kg}$ & $\mathrm{Kg}$ & $\mathrm{Kg}$ & Pc & Ps & $\mathbf{K r}$ \\
\hline K-225 & $7,5-10$ & 0,520 & 186,76 & 359,15 & 739,43 & 1109,15 & 1 & 2 & 3 \\
\hline
\end{tabular}

\section{Tulangan/Besi}

Untuk pekerjaan pembesian, tulangan pokok yang digunakan adalah besi polos/ulir dengan mutu $2400 \mathrm{~kg} / \mathrm{cm}^{2}$. Dengan diameter untuk tulangan pokok yang digunakan adalah : D14 mm, $\varnothing 12 \mathrm{~mm}$. Untuk tulangan sengkang digunakan besi dengan $\varnothing 8 \mathrm{~mm}$ dan $\varnothing 6 \mathrm{~mm}$, kawat ikat yang digunakan $\varnothing 1 \mathrm{~mm}$ dimana untuk kawat ikat digunakan $\pm 0,5 \mathrm{~kg}$ dalam $1 \mathrm{~m}^{3}$.

\section{Perhitungan Volume Beton Bertulang Sloof}

Balok sloof yang digunakan berukuran 20/25 $\mathrm{cm}, 20 / 30 \mathrm{~cm}, 25 / 40 \mathrm{~cm}$ dan $30 / 50 \mathrm{~cm}$. Untuk perhitungan balok sloof dihitung dengan rumus 2.1

\section{Kolom}

Ukuran kolom adalah $40 / 40 \mathrm{~cm}, 30 / 30 \mathrm{~cm}$, 20/30 cm, $13 / 25 \mathrm{~cm}, 20 / 40 \mathrm{~cm}, 30 / 40 \mathrm{~cm}$ dan $13 / 13 \mathrm{~cm}$ untuk kolom praktis. Volume dihitung dengan rumus 2.2

\section{Balok Lantai}

Ukuran balok lantai adalah $35 / 60 \mathrm{~cm}$, $30 / 50 \mathrm{~cm}, 25 / 40 \mathrm{~cm}$, dan 20/30 cm. Volume dihitung dengan rumus 2.3

\section{Ring Balok}

Ukuran ring balok adalah $25 / 35 \mathrm{~cm}$. Volume dihitung dengan rumus 2.4

\section{Perhitungan Volume Untuk Pembesian \\ Perhitungan Volume Tulangan sloof}

\section{a. Tulangan atas}

Berdasarkan SK SNI T-15-1991-03 halaman 449 untuk tulangan atas pada sloof, memakai kait $1 / 4$ lingkaran $\left(90^{\circ}\right)$. Maka digunakan rumus 2.5 2.11

\section{b. Tulangan tengah dan bawah}

Berdasarkan SK SNI T-15-1991-03 halaman 449 untuk tulangan tengah dan tulangan bawah pada sloof, memakai kait $1 / 2$ lingkaran $\left(180^{\circ}\right)$. Maka digunakan rumus $2.12-2.17$.

\section{c. Tulangan sengkang pada sloof}

Sengkang pada sloof terdiri dari 2 bagian yaitu:

- Untuk sengkang sloof bagian tumpuan: $\varnothing 8$ $100 \mathrm{~mm}$

- Untuk sengkang sloof bagian lapangan: Ø8 $150 \mathrm{~mm}$

Volume tulangan sengkang pada sloof dihitung dengan menggunakan rumus 2.18-2.24.

\section{Perhitungan Volume Tulangan Kolom}

Tulangan kolom terdiri dari tulangan pokok, dan tulangan sengkang

a. Tulangan pokok (Tulangan 1-2-3-4-5-6-7-89-10-11-12)

Perhitungan untuk tulangan kolom dapat dilakukan dengan menggunakan rumus 2.25-2.31. 


\section{b. Tulangan sengkang pada kolom}

Volume tulangan sengkang pada kolom dapat dihitung dengan menggunakan rumus 2.182.25 .

\section{Perhitungan Volume Tulangan balok lantai}

Tulangan balok lantai terdiri dari tulangan atas, tulangan tengah, tulangan bawah, dan tulangan sengkang.

\section{a. Tulangan Atas}

Berdasarkan SK SNI T-151-1991-03 halaman 449 untuk tulangan atas pada balok, memakai kait $1 / 4$ lingkaran $\left(90^{\circ}\right)$. Maka digunakan rumus $2.12-2.17$.

\section{b. Tulangan tengah dan bawah}

Berdasarkan SK SNI T-15-1991-03 halaman 449 untuk tulangan tengah dan tulangan bawah pada balok, memakai kait $1 / 2$ lingkaran $\left(180^{\circ}\right)$, digunakan rumus $2.12-2.17$.

\section{c. Tulangan sengkang pada balok lantai}

Sengkang pada balok lantai terdiri dari 2 bagian yaitu:

- Untuk sengkang balok lantai bagian tumpuan: $\varnothing 10-100 \mathrm{~mm}$

- Untuk sengkang balok lantai bagian lapangan: $\varnothing 10-150 \mathrm{~mm}$

Volume tulangan sengkang pada balok lantai dihitung dengan menggunakan rumus 2.182.25 .

\section{Perhitungan Volume Tulangan Ring Balok}

Tulangan ring balok terdiri dari tulangan atas, tulangan tengah, tulangan bawah, dan tulangan sengkang.

\section{a. Tulangan Atas}

Berdasarkan SK SNI T-151-1991-03 halaman 449 untuk tulangan atas pada balok, memakai kait $1 / 4$ lingkaran $\left(90^{\circ}\right)$. ). Maka digunakan rumus $2.12-2.17$.

\section{b. Tulangan tengah dan bawah}

Berdasarkan SK SNI T-15-1991-03 halaman 449 untuk tulangan tengah dan tulangan bawah pada balok, memakai kait $1 / 2$ lingkaran $\left(180^{\circ}\right)$. Maka digunakan rumus $2.12-2.17$.

\section{c. Tulangan sengkang pada ring balok}

Sengkang pada ring balok terdiri dari 2 bagian yaitu:

- Untuk sengkang balok bagian tumpuan: $\varnothing 8$ $100 \mathrm{~mm}$

- Untuk sengkang balok bagian lapangan: Ø8 $150 \mathrm{~mm}$

Volume tulangan sengkang pada ring balok dihitung dengan menggunakan rumus 2.18-2.25.

\section{Perhitungan Biaya Material}

Perhitungan biaya material dapat dilakukan dengan menggunakan rumus 2.32 


\section{HASIL DAN PEMBAHASAN}

Hasil

\section{Perhitungan Volume Beton}

Hasil perhitungan volume beton proyek dapat dilihat pada Tabel 4.1.

Tabel 4.1 Tabel hasil perhitungan volume beton

\begin{tabular}{|c|c|c|}
\hline \multirow{2}{*}{ No } & \multicolumn{2}{|c|}{ Hasil Perhitungan Volume } \\
\hline & Jenis volume & Hasil perhitungan \\
\hline $\begin{array}{l}1 \\
2 \\
3 \\
4\end{array}$ & $\begin{array}{l}\text { Sloof } \\
\text { Kolom } \\
\text { Balok } \\
\text { Ring Balok }\end{array}$ & $\begin{array}{r}53,89 \mathrm{~m}^{3} \\
100,27 \mathrm{~m}^{3} \\
69,99 \mathrm{~m}^{3} \\
13,05 \mathrm{~m}^{3}\end{array}$ \\
\hline & Jumlah & $237,20 \mathrm{~m}^{3}$ \\
\hline
\end{tabular}

\section{Perhitungan Volume Material Pembentuk Beton}

Tabel 4.2 Perhitungan Kebutuhan Material Beton

\begin{tabular}{|c|c|c|c|c|}
\hline No. & Uraian & $\begin{array}{c}\text { Koefisien } \\
(\text { Kg) }\end{array}$ & $\begin{array}{c}\text { Volume } \\
\left(\mathbf{m}^{3}\right)\end{array}$ & $\begin{array}{l}\text { Total } \\
\text { (Kg) }\end{array}$ \\
\hline \multirow{5}{*}{1} & \multicolumn{4}{|l|}{ Material Sloof } \\
\hline & Semen Portland & 359,15 & 53,89 & 19354,59 \\
\hline & Pasir Beton & 739,43 & 53,89 & 39847,88 \\
\hline & Kerikil & 1109,15 & 53,89 & 59772,09 \\
\hline & Air & 186,76 & 53,89 & 10064,50 \\
\hline \multirow{5}{*}{2} & \multicolumn{4}{|l|}{ Material Kolom } \\
\hline & Semen Portland & 359,15 & 100,27 & 36011,97 \\
\hline & Pasir Beton & 739,43 & 100,27 & 74142,65 \\
\hline & Kerikil & 1109,15 & 100,27 & 111214,47 \\
\hline & Air & 186,76 & 100,27 & 18726,43 \\
\hline \multirow{5}{*}{3} & \multicolumn{4}{|c|}{ Material Balok Lantai } \\
\hline & \begin{tabular}{|l|} 
Semen Portland \\
\end{tabular} & 359,15 & 69,99 & 25136,91 \\
\hline & Pasir Beton & 739,43 & 69,99 & 51752,71 \\
\hline & Kerikil & 1109,15 & 69,99 & 77629,41 \\
\hline & Air & 186,76 & 69,99 & 13071,33 \\
\hline \multirow{5}{*}{4} & \multicolumn{4}{|c|}{ Material Ring Balok } \\
\hline & \begin{tabular}{|l|} 
Semen Portland \\
\end{tabular} & 359,15 & 13,05 & 4686,91 \\
\hline & Pasir Beton & 739,43 & 13,05 & 9649,56 \\
\hline & Kerikil & 1109,15 & 13,05 & 14474,41 \\
\hline & Air & 186,76 & 13,05 & 2437,22 \\
\hline
\end{tabular}

\section{Perhitungan Volume Material Pembesian}

a. Perhitungan volume tulangan sloof

Tabel 4.3 Rekapitulasi Tulangan Sloof

\begin{tabular}{|c|c|r|}
\hline No. & \multicolumn{1}{|c|}{ Uraian Jenis Besi } & \multicolumn{1}{c|}{$\begin{array}{c}\text { Total Volume } \\
\text { (Kg) }\end{array}$} \\
\hline 1 & $\varnothing 6 \mathrm{~mm}$ & 43,929 \\
\hline 2 & $\varnothing 8 \mathrm{~mm}$ & 2600,206 \\
\hline 3 & $\varnothing 12 \mathrm{~mm}$ & 116,487 \\
\hline 4 & $D 14 \mathrm{~mm}$ & 5445,617 \\
\hline
\end{tabular}

b. Perhitungan volume tulangan kolom

Tabel 4.4 Rekapitulasi Tulangan Kolom

\begin{tabular}{|c|c|r|}
\hline No. & \multicolumn{1}{|c|}{ Uraian Jenis Besi } & $\begin{array}{c}\text { Total Volume } \\
\text { (Kg) }\end{array}$ \\
\hline 1 & $\varnothing 6 \mathrm{~mm}$ & 939,095 \\
\hline 2 & $\varnothing 8 \mathrm{~mm}$ & 3697,679 \\
\hline 3 & $\varnothing 12 \mathrm{~mm}$ & 2463,998 \\
\hline 4 & $\mathrm{D} 14 \mathrm{~mm}$ & 8232,244 \\
\hline
\end{tabular}


c. Perhitungan volume tulangan balok lantai

Tabel 4.5 Rekapitulasi Pembesian Balok

\begin{tabular}{|c|l|c|}
\hline No. & \multicolumn{1}{|c|}{ Uraian Jenis Besi } & $\begin{array}{c}\text { Total Volume } \\
(\text { Kg) }\end{array}$ \\
\hline 1 & $\varnothing 6 \mathrm{~mm}$ & - \\
\hline 2 & $\varnothing 8 \mathrm{~mm}$ & 2466,504 \\
\hline 3 & $\varnothing 12 \mathrm{~mm}$ & - \\
\hline 4 & $\mathrm{D} 14 \mathrm{~mm}$ & 7643,589 \\
\hline
\end{tabular}

d. Perhitungan volume tulangan ring balok

Tabel 4.6 Rekapitulasi Pembesian Ring Balok

\begin{tabular}{|c|l|c|}
\hline No. & \multicolumn{1}{|c|}{ Uraian Jenis Besi } & $\begin{array}{c}\text { Total Volume } \\
(\text { Kg) }\end{array}$ \\
\hline 1 & $\varnothing 6 \mathrm{~mm}$ & - \\
\hline 2 & $\varnothing \quad 8 \mathrm{~mm}$ & 1066,617 \\
\hline 3 & $\varnothing 12 \mathrm{~mm}$ & - \\
\hline 4 & $\mathrm{D} 14 \mathrm{~mm}$ & 356,749 \\
\hline
\end{tabular}

e. Perhitungan Volume Kawat Ikat $\varnothing 1 \mathrm{~mm}$

Pemakaian kawat ikat dapat dihitung berdasarkan volume beton dengan pemakaian $\pm 0,5 \mathrm{~kg}$ dalam $1 \mathrm{~m}^{3}$.

Kawat ikat $\quad=0,5 \mathrm{~kg} \times 237,20 \mathrm{~m}^{3}$

$$
=118,6 \mathrm{Kg}
$$

Tabel 4.7 Konversi hasil perhitungan kebutuhan material

\begin{tabular}{|c|c|c|c|c|c|c|c|c|c|}
\hline \multirow{2}{*}{ Konversi } & \multicolumn{4}{|c|}{ Material Beton } & \multicolumn{5}{|c|}{ Material Pembesian } \\
\hline & Semen $(\mathrm{Pc})$ & \begin{tabular}{ll|} 
Pasir $(\mathrm{Ps})$ \\
\end{tabular} & Kerikil $(\mathrm{Kr})$ & Air & Kawat ikat & $\emptyset 6 \mathrm{~mm}$ & $\emptyset 8 \mathrm{~mm}$ & $\emptyset 12 \mathrm{~mm}$ & $\mathrm{D} 14 \mathrm{~mm}$ \\
\hline Total Awal & 2129,760 & 69,739 & $\begin{array}{r}99,392 \\
\end{array}$ & 44299,472 & 118,600 & 4428,038 & 24888,624 & 2933,020242 & 19129,200 \\
\hline $\begin{array}{l}\text { Total Akhir } \\
(\text { Total Awal + 10\%) }\end{array}$ & 2342,735 & 76,713 & 109,331 & 48729,419 & 130,460 & 4870,842 & 27377,486 & 3226,322266 & 21042,120 \\
\hline Dibulatkan & $2343 \mathrm{Zak}$ & $\approx 20$ Truk & $\approx 28$ Truk & $\approx 10$ Truk Tangki & $\approx 131 \mathrm{Kg}$ & $\approx 488$ Batang & $\approx 2738$ Batang & $\approx 269$ Batang & $\approx 1754$ Batang \\
\hline
\end{tabular}

\section{Perhitungan Kebutuhan Anggaran Biaya Pengadaan Material menurut SK SNI T-15-1991-03}

Kebutuhan anggaran biaya untuk pengadaan material dengan satuan nilai harga material di pasaran pada periode Juni 2011 dengan rincian sebagai berikut;
1. Semen (Pc) Andalas $40 \mathrm{~kg} / \mathrm{zak}$
$=$ Rp. 40.000,00 / zak (40 kg)
2. Pasir dari Indra Puri
$=$ Rp. $400.000,00 /$ truk (kapasitas $4 \mathrm{~m}^{3}$ )
3. Kerikil dari Indra Puri
$=$ Rp. 350.000,00/ truck (kapasitas $4 \mathrm{~m}^{3}$ )
4. Air dari PAM
$=$ Rp.100.000,00/tangki (kapasitas 5000 liter)
5. Kawat beton $1 \mathrm{~mm}$
$=$ Rp. $12 \cdot 000,00 / \mathrm{kg}$
6. Besi $\varnothing 6 \mathrm{~mm}$, panjang $10 \mathrm{~m}$
$=$ Rp. $25 \cdot 000,00 /$ batang $(\mathrm{L} 10 \mathrm{~m})$
7. Besi $\varnothing 8 \mathrm{~mm}$, panjang $10 \mathrm{~m}$
$=$ Rp. 39.000,00/batang $(\mathrm{L} 10 \mathrm{~m})$
8. Besi $\varnothing 12 \mathrm{~mm}$, panjang $12 \mathrm{~m}$
$=R p . .80 .500,00 /$ batang $(L 12 \mathrm{~m})$
9. Besi D14 mm, panjang $12 \mathrm{~m}$
$=R p . .99 .000,00 /$ batang $(\mathrm{L} 12 \mathrm{~m})$ 
maka kebutuhan biaya untuk pengadaan material adalah sebagai berikut.
1. Semen $(\mathrm{Pc})$
: 2343 zak
$x \quad$ Rp. 40.000
$=R p$
93.720 .000
2. Pasir
: 20 truk
$X$ Rp. $400.000=R p$
8.000 .000
3. Kerikil
: 28 truk
$x$
Rp. $350.000=R p$
9.800 .000
4. Air
: 10 tangki $\mathrm{x}$
Rp. 100.000
$=R p$
1.000 .000
5. Kawat beton : $131 \mathrm{~kg}$
$x$ Rp. $12.000=R p$
1.572 .000
6. Besi $\varnothing 6 \mathrm{~mm}$ : 488 batang $\mathrm{x}$
Rp. $25.000=R p$
12.200 .000
7. Besi $\varnothing 8 \mathrm{~mm}: 2738$ batang $x$
Rp. $\quad 39.000$
$=R p$
106.782 .000
8. Besi $\varnothing 12 \mathrm{~mm}$ : 269 batang $x$
Rp. 80.500
$=R p$
21.654 .500
9. Besi D14 mm : 1754 batang $x$
Rp. 99.000
$=\operatorname{Rp} 173.646 .000$

Total anggaran biaya untuk pengadaan material adalah

Rp $\quad 428.374 .500$

Dari hasil perhitungan Tabel 4.13 dapat diketahui bahwa untuk pengadaan material beton dan pembesian (sloof, kolom, balok dan ring balok) adalah sebesar $\mathrm{Rp} 428.373 .500$ atau sebesar 34, 86\% dari harga bangunan secara keseluruhan yaitu $\mathrm{Rp}$ 1.229.000.000,00. Dengan persentase pengadaan material terbesar terletak pada pengadaan Besi D $14 \mathrm{~mm}$ sebanyak 1754 batang dengan harga $\mathrm{Rp} 173.646 .000$ atau sebesar $14,13 \%$ dari harga bangunan secara keseluruhan.

Perhitungan Kebutuhan Anggaran Biaya Pengadaan Material Beton menurut SNI DT 91-00008-2007

a. Material Beton

Kebutuhan anggaran biaya untuk pengadaan material beton dengan menggunakan analisa SNI DT 91 - 00008 - 2007 dan harga material di pasaran pada periode Juni 2011 adalah sebagai berikut : 


\begin{tabular}{|c|c|c|c|c|c|c|c|c|}
\hline \multicolumn{9}{|c|}{ SNI DT - 910008 - 2007} \\
\hline \multirow[t]{5}{*}{6.7} & Membuat $1 \mathrm{~m} 3$ beton & Itu f' & 19,3 MPa (K 225), slump (12 \pm 2 & $\mathrm{~m}, \mathrm{w}$ & $/ c=0$ & & & \\
\hline & 371,000 & $\mathrm{~kg}$ & $\mathrm{PC}$ & @ & $\mathrm{Rp}$ & $1.000,00$ & $\mathrm{Rp}$ & $371.000,00$ \\
\hline & 698,000 & $\mathrm{~kg}$ & Pasir Beton & @ & $\mathrm{Rp}$ & 39,76 & $\mathrm{Rp}$ & $27.753,48$ \\
\hline & 1047,000 & $\mathrm{~kg}$ & Bahan KR (maksimum $30 \mathrm{~mm}$ ) & @ & $\mathrm{Rp}$ & 33,06 & $\mathrm{Rp}$ & $34.609,94$ \\
\hline & 215,000 & Itr & Air & @ & $\mathrm{Rp}$ & 20,00 & $\mathrm{Rp}$ & $4.300,00$ \\
\hline & & & & & & & $\mathrm{Rp}$ & 437.663 \\
\hline
\end{tabular}

Tabel 4.9 Kebutuhan biaya untuk pengadaan material beton menurut SNI DT 91-00008-2007

\begin{tabular}{|c|c|c|c|c|c|c|}
\hline \multirow{2}{*}{$\begin{array}{l}\text { Uraian Pekerjaan } \\
\text { Sloof } 20 \times 25\end{array}$} & \multirow{2}{*}{$\begin{array}{r}\text { Volume } \\
1,138\end{array}$} & \multirow{2}{*}{$\frac{\text { Satuan }}{\mathrm{m} 3}$} & \multicolumn{2}{|c|}{ Harga Satuan } & \multicolumn{2}{|c|}{ Jumlah Harga } \\
\hline & & & Rp & 437.663 & $\mathrm{Rp}$ & $497.842,13$ \\
\hline Sloof $25 \times 40$ & 33,260 & m3 & $\mathrm{Rp}$ & 437.663 & $\mathrm{Rp}$ & $14.556 .685,18$ \\
\hline Sloof $20 \times 30$ & 3,006 & $\mathrm{~m} 3$ & $\mathrm{Rp}$ & 437.663 & $\mathrm{Rp}$ & $1.315 .616,23$ \\
\hline Sloof $30 \times 50$ & 16,485 & $\mathrm{~m} 3$ & $\mathrm{Rp}$ & 437.663 & $\mathrm{Rp}$ & $7.214 .881,39$ \\
\hline \multicolumn{5}{|l|}{ Sub Total } & $R p$ & $23.585 .024,93$ \\
\hline Kolok K1 (40 x 40) & 76,928 & m3 & $\mathrm{Rp}$ & 437.663 & $\mathrm{Rp}$ & $33.668 .571,18$ \\
\hline Kolom K2 (30 x 30) & 5,148 & $\mathrm{~m} 3$ & $\mathrm{Rp}$ & 437.663 & $\mathrm{Rp}$ & 2.253.091,26 \\
\hline Kolom K3 $(20 \times 30)$ & 1,548 & $\mathrm{~m} 3$ & $\mathrm{Rp}$ & 437.663 & $\mathrm{Rp}$ & $677.502,97$ \\
\hline Kolom K4 (13 x 25) & 8,476 & m3 & $\mathrm{Rp}$ & 437.663 & $\mathrm{Rp}$ & $3.709 .635,10$ \\
\hline Kolom K5 (20 x 40) & 1,200 & $\mathrm{~m} 3$ & $\mathrm{Rp}$ & 437.663 & $\mathrm{Rp}$ & $525.196,10$ \\
\hline Kolom K6 (30 x 40) & 3,600 & m3 & $\mathrm{Rp}$ & 437.663 & $\mathrm{Rp}$ & $1.575 .588,29$ \\
\hline Kolom Praktis K7 $(13 \times 13)$ & 3,372 & m3 & $\mathrm{Rp}$ & 437.663 & $\mathrm{Rp}$ & $1.475 .604,09$ \\
\hline \multicolumn{5}{|l|}{ Sub Total } & $\boldsymbol{R p}$ & $43.885 .188,99$ \\
\hline Balok $35 \times 60$ & 16,044 & m3 & $\mathrm{Rp}$ & 437.663 & $\mathrm{Rp}$ & $7.021 .871,83$ \\
\hline Balok $30 \times 50$ & 42,060 & m3 & $\mathrm{Rp}$ & 437.663 & $\mathrm{Rp}$ & $18.408 .123,23$ \\
\hline Balok $25 \times 40$ & 8,260 & m3 & Rp & 437.663 & $\mathrm{Rp}$ & $3.615 .099,81$ \\
\hline Balok $20 \times 30$ & 3,630 & $\mathrm{~m} 3$ & $\mathrm{Rp}$ & 437.663 & $\mathrm{Rp}$ & $1.588 .718,20$ \\
\hline \multicolumn{5}{|l|}{ Sub Total } & $R p$ & $30.633 .813,06$ \\
\hline Ring Balok $25 \times 35$ & 13,053 & $\mathrm{~m} 3$ & $\mathrm{Rp}$ & 437.663 & $\mathrm{Rp}$ & $5.712 .601,72$ \\
\hline \multicolumn{5}{|l|}{ Sub Total } & $R p$ & $5.712 .601,72$ \\
\hline \multicolumn{5}{|l|}{ Total Biaya } & Rp & $103.816 .628,71$ \\
\hline \multicolumn{5}{|c|}{ Dibulatkan } & $R p$ & $103.816 .600,00$ \\
\hline
\end{tabular}

a. Material Pembesian

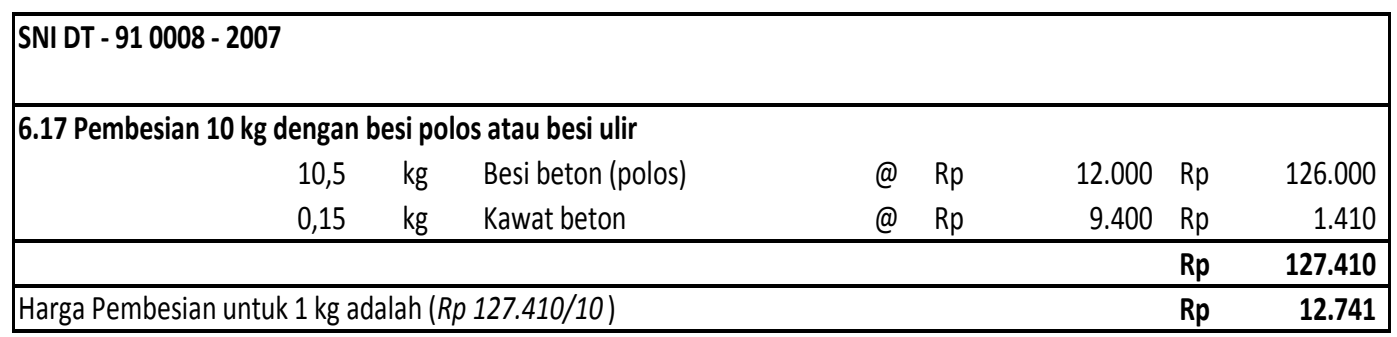

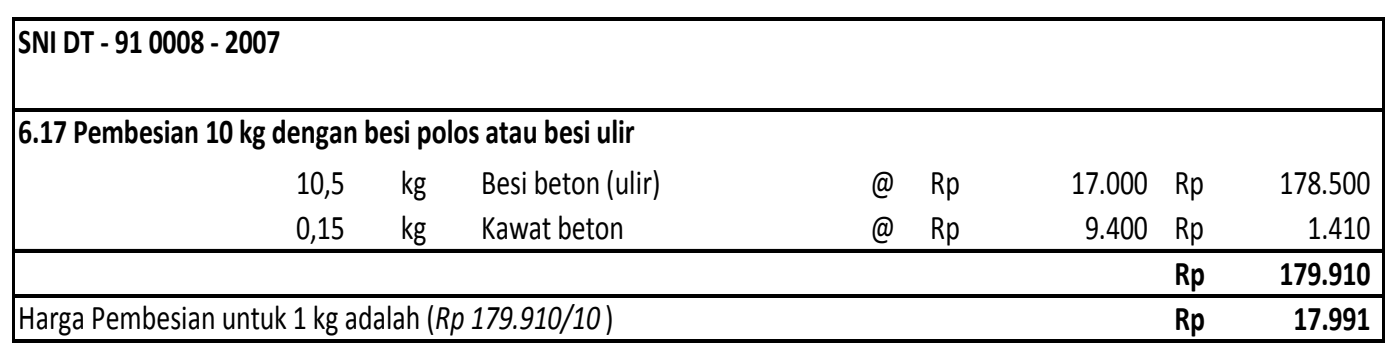


Tabel 4.10 Kebutuhan biaya untuk pengadaan material pembesian menurut SNI DT 91-00008-2007

\begin{tabular}{|c|c|c|c|c|c|c|}
\hline Uraian Pekerjaan & Volume & Satuan & \multicolumn{2}{|c|}{ Harga Satuan } & \multicolumn{2}{|c|}{ Jumlah Harga } \\
\hline \multicolumn{7}{|l|}{ Sloof } \\
\hline Tulangan $6 \mathrm{~mm}$ & 43,9294 & kg & $\mathrm{Rp}$ & 12.741 & $\mathrm{Rp}$ & $559.704,33$ \\
\hline Tulangan $8 \mathrm{~mm}$ & 2600,21 & kg & $\mathrm{Rp}$ & 12.741 & $\mathrm{Rp}$ & $33.129 .221,53$ \\
\hline Tulangan $12 \mathrm{~mm}$ & 140,524 & $\mathrm{~kg}$ & $\mathrm{Rp}$ & 12.741 & $\mathrm{Rp}$ & $1.790 .411,92$ \\
\hline Tulangan D $14 \mathrm{~mm}$ & 5445,62 & kg & $\mathrm{Rp}$ & 17.991 & $\mathrm{Rp}$ & $97.972 .100,73$ \\
\hline \multicolumn{5}{|l|}{ Sub Total } & $\overline{R p}$ & $133.451 .438,51$ \\
\hline \multicolumn{7}{|l|}{ Kolom } \\
\hline Tulangan $6 \mathrm{~mm}$ & 939,095 & kg & $\mathrm{Rp}$ & 12.741 & $\mathrm{Rp}$ & $11.965 .010,66$ \\
\hline Tulangan $8 \mathrm{~mm}$ & 3697,68 & kg & $\mathrm{Rp}$ & 12.741 & $\mathrm{Rp}$ & $47.112 .126,36$ \\
\hline Tulangan $12 \mathrm{~mm}$ & 2464 & $\mathrm{~kg}$ & $\mathrm{Rp}$ & 12.741 & $\mathrm{Rp}$ & $31.393 .802,56$ \\
\hline Tulangan D $14 \mathrm{~mm}$ & 8232,24 & $\mathrm{~kg}$ & $\mathrm{Rp}$ & 17.991 & $\mathrm{Rp}$ & $148.106 .301,85$ \\
\hline \multicolumn{5}{|l|}{ Sub Total } & $\boldsymbol{R p}$ & $238.577 .241,42$ \\
\hline \multicolumn{7}{|l|}{ Balok } \\
\hline Tulangan $8 \mathrm{~mm}$ & 2466,5 & kg & $\mathrm{Rp}$ & 12.741 & $\mathrm{Rp}$ & $31.425 .733,57$ \\
\hline Tulangan D $14 \mathrm{~mm}$ & 7643,59 & $\mathrm{~kg}$ & $\mathrm{Rp}$ & 17.991 & $\mathrm{Rp}$ & $137.515 .804,29$ \\
\hline \multicolumn{5}{|l|}{ Sub Total } & $\overline{R p}$ & $168.941 .537,86$ \\
\hline \multicolumn{7}{|l|}{ Ring Balok } \\
\hline Tulangan $8 \mathrm{~mm}$ & 1066,62 & $\mathrm{~kg}$ & $\mathrm{Rp}$ & 12.741 & $\mathrm{Rp}$ & $13.589 .771,05$ \\
\hline Tulangan D $14 \mathrm{~mm}$ & 1824,88 & kg & $\mathrm{Rp}$ & 17.991 & $\mathrm{Rp}$ & $32.831 .448,75$ \\
\hline \multicolumn{5}{|l|}{ Sub Total } & $\boldsymbol{R p}$ & $46.421 .219,80$ \\
\hline \multicolumn{5}{|l|}{ Total Biaya } & $\mathbf{R p}$ & $587.391 .437,60$ \\
\hline \multicolumn{5}{|c|}{ "Dibulatkan } & $\boldsymbol{R p}$ & $587.391 .000,00$ \\
\hline
\end{tabular}

\section{Perbandingan Biaya}

Perbandingan harga untuk pengadaan kebutuhan material dilapangan menggunakan perhitungan metode SK-SNI T-15-1991-03 dibandingkan dengan metode perhitungan SNI DT $91-00008-2007$ adalah sebagai berikut ;

SK-SNI T-15-1991-03 : Rp $428.374 .500,00$

SNI DT 91-00008-2007 : Rp 691.207.600,00

Terdapat selisih harga sebesar $\mathrm{Rp}$ 141.315.100,00 dengan harga material sesuai dengan harga pasaran Juni 2011, terdapat perbedaan biaya sebesar $24,81 \%$.

\section{Pembahasan}

Sebagai penyajian hasil dari penelitian ini berdasarkan data Engineer Estimate (EE) yang diperoleh dari kontraktor pelaksana yaitu PT. Tunggai Consultant dimana perhitungan EE menggunakan analisa SNI 2007 terdapat perbedaan harga untuk pengadaan material sebesar $24,81 \%$, dibandingkan dengan metode perhitungan yang dipakai sebagai referensi penulis yaitu SK SNI T-15-1991-03.

Setelah penulis pelajari bahwa dengan menggunakan harga pada periode Juni 2011 baik perhitungan menggunakan metode SK SNI T-151991-03 dan perhitungan menurut Engineer Estimate (EE) terdapat perbedaan harga yang sangat signifikan, perbedaan ini berasal dari akibat berbedanya koefisien material pembentuk beton dan pembesian yang terdapat pada dua metode tersebut. Dalam SNI 2007 memiliki koefisien lebih besar dibandingkan dengan SK SNI T-15-1991-03, oleh karena itu kebutuhan material yang diperlukan akan berbeda. 


\section{KESIMPULAN}

\section{Kesimpulan}

Dari hasil uraian, diskusi, dan perhitungan serta dengan mempertimbangkan faktor nilai kehilangan volume sebesar $10 \%$, maka dapat disimpulkan bahwa untuk pengadaan material untuk beton struktural pada Proyek Pembangunan Gedung Dinas Bina Marga Dan Cipta Karya Kabupaten Aceh Besar berdasarkan perhitungan menggunakan metode SK SNI T-15-1991-03 adalah sebagai berikut:

1. Semen (Pc) Andalas 40 kg/zak: 2343 zak

2. Pasir

3. Kerikil $: 77 \mathrm{~m}^{3} \approx 20$ truk

4. Air PAM : 48730 Liter $\approx 10$ truk tangki

5. Kawat beton $1 \mathrm{~mm}: 131 \mathrm{Kg}$

6. Besi $\varnothing 6 \mathrm{~mm}$ panjang $10 \mathrm{~m}: 488$ Batang

7. Besi $\varnothing 8 \mathrm{~mm}$ panjang $10 \mathrm{~m}: 2738$ Batang

8. Besi $\varnothing 12 \mathrm{~mm}$ panjang $12 \mathrm{~m}$ : 269 Batang

9. Besi D14 mm panjang $12 \mathrm{~m}$ : 1754 Batang

Dengan kebutuhan biaya untuk pengadaan material beton struktural adalah sebesar $\mathrm{Rp}$. 428.349.500,00- atau $34,85 \%$ dari total biaya secara keseluruhan sebesar Rp 1.229.000.000,00. Dan selisih perhitungan biaya menurut metode SK-SNI-T-151991-03 dan SNI 2007 EnggineerEstimate (EE) adalah sebesar Rp $141.315 .100,00$ atau $24,81 \%$.

\section{DAFTAR PUSTAKA}

Anonim, 2010, Koperasi Meugah Pande, Gambar Bestek Proyek Pembangunan Gedung Dinas Bina Marga Dan Cipta Karya Kabupaten Aceh Besar, Banda Aceh.

Anonim, 1991, SK SNI T-15-1991-03, Departemen Pekerjaan Umum, Bandung, tentang Perbandingan Campuran Beton Tiap $\mathrm{m}^{3}$ Dengan Dasar Berat.

Dipohusodo, Istimawan, 1996, Struktur Beton Bertulang, Gramedia, Jakarta.

Soedradjat, A, 1984, Analisa (Cara Modern) Anggaran Biaya Pelaksanaan, Nova, Bandung. 